\title{
Relationship between Charismatic Authority and the Administration of Teachers to the Quality of Elementary School Instruction
}

\author{
Maulana Bayu Isnarofik ${ }^{1}$, Ine Kusuma Aryani ${ }^{2}$, Yahya Sudarya ${ }^{3}$, Siti Yunia $^{4}$, \\ Poppy Andhi Utami ${ }^{5}$ \\ $\left\{\right.$ maulanabayu10@gmail.com ${ }^{1}, \underline{\text { inepascapendas@gmail.com² }}$, \\ yahyasudarya@yahoo.com ${ }^{3}$, sitiyunia0410@gmail.com ${ }^{4}$, \\ poppyandhiutami2019@gmail.com ${ }^{5}$ \} \\ ${ }^{1}$ SD N Watujaran \\ ${ }^{2,3}$ Universitas Muhammadiyah Purwokerto \\ ${ }^{4}$ SD IT Tahfidzul Qur'an Nurul Jannah \\ ${ }^{5}$ SD N Panambangan
}

\begin{abstract}
The article aims to determine the relationship between charismatic leadership and management of educators and education personnel to make strides the quality of elementary school instruction. Charismatic leadership is a quality that stands out in a leader in influencing educators and education personnel to advance the quality of primary school education. This article uses a literature review study, examining various relevant sources related to the existing discussion themes. While the charismatic leadership model in which organizational culture is the key, then the leader involves his leadership behavior which will later have an impact on followers, both individual followers, and group followers and ultimately will also influence the results of leadership and show that the relationship of charismatic leadership in the management of educators and education personnel can improve the quality of primary school education.
\end{abstract}

Keywords: Charismatic Leadership, Management, Elementary School

\section{Introduction}

A vision and mission statement are required for any organization. In other words, the organization must fulfill its objectives [1]. The reason is simple, and an organization is an institution that attracts people who are willing to work together to achieve common goals, shared goals, and individual objectives. The readiness of human resources involved in the education process determines the readiness of human resources involved in the education process. One of the determinants of high and low quality educational outcomes is the teacher. Various parties who feel the impact of educational products in which teachers play a role have always highlighted the presence of teachers at the forefront of the education and teaching process.

A charismatic authority style of the leader can boost instructors' innovation in assignments and work [2]. Innovative teachers will have an impact on the charismatic authority of the vital. 
This authority model is a marvel for shaping the quality of instruction in the future with the hope of making way better advancement work.

Many people believe that being a leader is simple. Confirmation can be seen when pioneers make decisions from the state level to the community level. People nominated themselves in droves because they believed they were capable of becoming leaders. It is not uncommon for them to dismiss each other, believing that they are more capable than their competitors. Siagian noted that the success of an organization depends on the quality of leadership contained in the organization concerned [3]. It even becomes a general belief if the quality of leadership held in an organization plays a very dominant role in the organization's success in carrying out its various activities.

The goal of leadership behavior theory is to identify personal behaviors that are associated with effective leadership. The theory of leadership behavior focuses on two aspects of leadership behavior: functions and leadership styles [4].

The success or failure of an organization in achieving its goals cannot be separated from the performance of its leader [5]. If the leader performs well, the organization will reach its objectives quickly, and vice versa. When the leader's performance is poor, the organization will struggle to meet its objectives. This is not to say that members of subordinates do not contribute to an organization's success; however, the leadership factor is biased.

\section{Literature Review}

Charismatic authority that expect that charisma is an person characteristic of a pioneer who can recognize him from other pioneers, particularly in terms of suggestions for motivation, acknowledgment, and back of subordinates [2]. The characteristics and behavior of pioneers are fundamental determinants of charismatic authority [1]. Charismatic pioneers are more likely to have a solid require for control, tall self-confidence, and a solid stand in their possess convictions and beliefs. Leadership behavior that clarifies how a charismatic pioneer influences the states of mind and behavior of subordinates includes [3]: (1) Convey an attractive vision; (2) Using solid and expressive shapes of communication when conveying the vision; (3) Taking individual dangers and making self-sacrifices to achieve that vision; (4) Role modeling of behavior reliable with that vision; and (6) Give authority to subordinates

Leadership or leading is an effort made by a person with all his abilities to influence, encourage, guide, direct, and motivate others to want to work with enthusiasm and confidence in achieving common goals. About the mission of education, leadership can be interpreted as an effort by the principal to influence, encourage, guide, direct, and mobilize school staff to work effectively to achieve predetermined educational and teaching goals [5].

Management is the art or skill of planning, directing, managing, and supervising so that all activities run well and produce goals to be accomplished together. Law No. 20 of 2003 concerning the National education system, articles 1, paragraphs 5 and 6 , what is meant by academic staff are members of the community who are devoted and appointed to support education budgeting while educators are educational staff who are qualified as teachers, lecturers, counselors, tutors, tutors,facilitator, and other designations according to their specificity, as well as participating in providing education [6]. 
Management of teaching staff and education is a necessary activity that begins with the entry of teaching and education personnel into the teaching organization and ends with the process of HR planning, recruitment, selection, placement, compensation, awards, educators, training/development, and dismissal [1][6]. Principals or madrasahs, scholarly units, regulatory staff, library staff, research facility specialists, administration of thought groups, and cleaning work force are all examples of instructional faculty.

\section{Method}

In this article, to analyze it utilizing logical survey strategies, implies a prepare or composing to dismember a logical ponder or inquire about. Perusing and composing audits or audits of logical papers such as theses, theses, books, and inquire about articles is one of the abilities understudies and scholastics must- have.

This activity aims to examine how far the development of science has gone and to strengthen the scientific basics possessed by the academic community. A review article is an article created to provide a clear picture of a study or research, whether it is the advantages or disadvantages of the object being checked on, or only combines several studies to strengthen the analysis in the study conducted [7].

Systematic Review (SR), or what is usually called a Systematic Literature Review (SLR), is a systematic way to collect, critically evaluate, integrate and present findings from various research studies on research questions or topics of interest. The SLR provides a way to assess the quality of existing evidence on a question or issue of interest. SLR offers a broader and more accurate level of understanding than traditional literature reviews [8].

SLR requires a more rigorous and well-defined approach, is more comprehensive, and specifies in detail the timeframe for which the literature is selected [9]. The SLR method is carried out systematically by following the steps and protocols that allow writing articles to avoid bias and subjective understanding of the researchers.

This article aims to explore more deeply the charismatic leadership model in educational institutions. The technique used is a systematic literature review to identify and classify some of the research results of leadership models. The method used in this article is a literature review, and its purpose is to assess, summarize, and communicate the results and implications of previous research. Literature reviews generally aim to describe the purpose of the evaluation, review, suggest how the article was evaluated, and identifies common mistakes in the report. 
Table of Research on the results of the Systematic Literature Review (SLR)

\begin{tabular}{|c|c|c|}
\hline Researcher and Year & Journal Articles & Research result \\
\hline AE Yusuf (2018) & $\begin{array}{l}\text { Hubungan Antara Gaya } \\
\text { Kepemimpinan Karismatik } \\
\text { Kepala Sekolah Dan } \\
\text { Kepribadian Dengan } \\
\text { Keinovatifan Guru. } \\
\text { (The Relationship Between } \\
\text { Head Charismatic } \\
\text { Leadership Styles School } \\
\text { And Personality With } \\
\text { Teacher Innovation) }\end{array}$ & $\begin{array}{l}\text { To test the hypothesis that } \\
\text { there is a positive } \\
\text { relationship between variable } \\
\mathrm{X}_{1} \text { and } \\
\text { variable Y required a } \\
\text { significance test of the } \\
\text { correlation coefficient, } \\
\text { namely the t-test. Testing } \\
\text { criteria } \\
\text { The significance of the } \\
\text { correlation coefficient is if } \\
\mathrm{t}_{\text {count }}>\mathrm{t}_{\text {table }}, \text { then the } \\
\text { correlation coefficient is } \\
\text { stated significantly. }\end{array}$ \\
\hline Rahmat Setiawan / 2014 & $\begin{array}{l}\text { Hubungan kepemimpinan } \\
\text { karismatik, kepemimpinan } \\
\text { transformasional dan } \\
\text { kepemimpinan transaksional } \\
\text { dengan kinerja bawahan } \\
\text { (Charismatic Leadership } \\
\text { Relationships, } \\
\text { Transformational Leadership } \\
\text { and Transactional Leadership } \\
\text { With Subordinate } \\
\text { Performance) }\end{array}$ & $\begin{array}{l}\text { The relationship between } \\
\text { charismatic administration } \\
\text { and executionsubordinates } \\
\text { cannot be clarified } \\
\text { straightforwardly, } \\
\text { but through the intervening } \\
\text { variable, to be specific } \\
\text { appropriateness } \\
\text { value and trust in esteem } \\
\text { congruence } \\
\text { pioneer. }\end{array}$ \\
\hline Budiadi (2018) & $\begin{array}{l}\text { Analisa Dampak } \\
\text { Kepemimpinan Karismatik } \\
\text { terhadap Kinerja Karyawan } \\
\text { di Pemerintah Daerah } \\
\text { Kabupaten Sukoharjo } \\
\text { (Analysis of the Impact of } \\
\text { Charismatic Leadership) }\end{array}$ & $\begin{array}{l}\text { The data analyzed were the } \\
\text { answers of } 65 \text { respondents to } \\
\text { the questionnaire } \\
\text { they have received. To } \\
\text { discover out the tall and moo } \\
\text { levels the appraisal score of } \\
\text { each variable, it is necessary } \\
\text { to have a criteria score. }\end{array}$ \\
\hline Nurlaili et al. (2018) & $\begin{array}{l}\text { Pengaruh Budaya Organisasi } \\
\text { dan Gaya Kepemimpinan } \\
\text { Terhadap Kinerja Guru } \\
\text { dengan Lingkungan Kerja } \\
\text { dan Kepuasan Kerja Sebagai } \\
\text { Varibel Intervening pada }\end{array}$ & $\begin{array}{l}\text { In compiling a plan for } \\
\text { improving the quality of } \\
\text { learning in schools, } \\
\text { performed various techniques } \\
\text { for collect data, both }\end{array}$ \\
\hline
\end{tabular}




\begin{tabular}{|c|c|c|}
\hline & $\begin{array}{l}\text { Guru SMA di Kecamatan } \\
\text { Dewantara Kabupaten Aceh } \\
\text { Utara (Principal Leadership } \\
\text { and Improving the Quality of } \\
\text { Learning in Schools) }\end{array}$ & $\begin{array}{l}\text { observations, interviews, or } \\
\text { use documents } \\
\text { school. From that activity, } \\
\text { then some of the problems } \\
\text { faced } \\
\text { the school, which then affects } \\
\text { quality of learning. }\end{array}$ \\
\hline Idris and Sari (2020) & $\begin{array}{l}\text { Pengaruh Kepemimpinan } \\
\text { dan Disiplin Kerja Terhadap } \\
\text { Kinerja Karyawan: Studi } \\
\text { Kasus PT Sucofindo } \\
\text { Palembang Indonesia. } \\
\text { Principal Leadership in } \\
\text { Effort Improve Teacher } \\
\text { Discipline }\end{array}$ & $\begin{array}{l}\text { Principal leadership in } \\
\text { building teacher discipline in } \\
\text { SD Luqman Alhakim's } \\
\text { integral is to optimize } \\
\text { Referent Power: } \\
\text { subordinates do something } \\
\text { because associates feel } \\
\text { amazed towards } \\
\text { leaders, associates feel } \\
\text { amazed or need to receive } \\
\text { blessings leader, so that the } \\
\text { teachers behave like a leader. }\end{array}$ \\
\hline
\end{tabular}

\section{Results and Discussion}

After analyzing various sources with, on the same theme it can be seen that, there are all sorts of phases and results indicated the effect on charismatic leadership at the school. There were a positive relationship in the quantitative criteria testing significant, a correlation coefficient by Setiawan study on the, charismatic leadership transformational leadership and leadership transaksional subordinate with performance[2]. It turns out that charismatic leadership and subordinate performance cannot be explained directly, but through the mediating variable, namely value suitability. therefore need to be distinguished from "leadership" as an identity or entity that has subordinates. Leadership provides energy in the form of trust and security, so that other people around them feel accommodated and sheltered. Leadership, thus, distributes wisdom, knowledge, solutions, and harmony to those around him.

In contrast to Budiadi who took the method with data analysis techniques to determine the Impact of Charismatic Leadership, which in this case can be taken from the results of multiple analysis on the technique used is the second hypothesis with the indicator that the most influential charismatic leadership is self-management indicators even though the influence is negative [11]. Meanwhile, Nurlaili et al. found in her observations with a research entitled Principal Leadership and Improving the Quality of Learning in Schools [12]. The principal contains more experiences of what has been done. In carrying out the mandate as a school principal to improve the quality of learning, the authors then use a management principle known as POAC. 
The principal is an element that becomes a symbol of education and education personnel. All of these HR elements in the management perspective lead to the Principal. So, how the principal controls human resources is the main determinant of the success of the management of educational organizations. One of the main elements that determine the quality of human resources is discipline. Idris and Sari found that there are 4 categories of approaches, namely authoritative, trait, behavioral, situational [13]. There are multidisciplinary values that are explained in other perspectives that may be different in previous studies.

\section{Conclusion}

In the leadership, the associates trust in the leader is one crucial factor that can improve the execution of subordinates. In the event that partners have total certainty within the pioneer, he will be willing to carry out what is requested by the pioneer and deliver all the capacities and potential he should carry out the assignments relegated by the pioneer. To progress the administration quality of authorities, it is suggested to read more about leadership styles and research on leadership styles. To see which leadership style is suitable for improving the performance of employees in public agencies.

Through the steps of Arranging, Organizing, Activating, and Organizing, endeavors have been made to move forward. Some of the problems faced by schools are, first, the low physical quality of learning spaces which endangers the safety of students and educators. Second, the low level of discipline of all parties in the school, including principals, educators, and students. Third, the low quality and quantity of facilities and infrastructure such as study desks and chairs.

\section{Reference}

[1] Wibowo WD, Wakhudin W. The Roles of Leadership Principal to Improving of Education Quality through Managerial Competence. Dinamika Jurnal Ilmiah Pendidikan Dasar. 2021 Sep 22;13(2):79-82.

[2] Setiawan R. Hubungan kepemimpinan karismatik, kepemimpinan transformasional dan kepemimpinan transaksional dengan kinerja bawahan. Jurnal Ekonomi dan Bisnis Airlangga. 2014;24(3):198-205.

[3] Siagian SP. Leadership theory and practice. Jakarta: Rineka Cipta. 2003.

[4] Sutianah E, Sunaryo W, Yusuf AE. Hubungan Antara Gaya Kepemimpinan Karismatik Kepala Sekolah Dan Kepribadian Dengan Keinovatifan Guru. Jurnal Manajemen Pendidikan. 2018 Jul 23;6(2):654-62.

[5] Bernarto I, Bachtiar D, Sudibjo N, Suryawan IN, Purwanto A, Asbari M. Effect of transformational leadership, perceived organizational support, job satisfaction toward life satisfaction: Evidences from indonesian teachers.

[6] Idris R. Manajemen Pendidikan dalam aplikasinya di sekolah. Makassar: Alauddin University Pres. 2014.

[7] Suryanarayana TM, Mistry PB. Review of literature. InPrincipal Component Regression for Crop Yield Estimation 2016 (pp. 27-37). Springer, Singapore. 
[8] Delgado-Rodríguez M, Sillero-Arenas M. Systematic review and meta-analysis. Medicina Intensiva (English Edition). 2018 Oct 1;42(7):444-53. Syamsudduha, St. 2014. Governance dalam manajemen pendidikan, Makassar,Alauddin University Press Sondang P. Siagian, 2003, Leadership Theory and Practice, Rineka Cipta: Jakarta

[9] Richardson K, Schoen M, French B, Umscheid CA, Mitchell MD, Arnold SE, Heidenreich PA, Rader DJ, Degoma EM. Statins and cognitive function: a systematic review. Annals of internal medicine. 2013 Nov 19;159(10):688-97.

[10] Sutianah E, Sunaryo W, Yusuf AE. Hubungan Antara Gaya Kepemimpinan Karismatik Kepala Sekolah Dan Kepribadian Dengan Keinovatifan Guru. Jurnal Manajemen Pendidikan. 2018 Jul 23;6(2):654-62.

[11] Budiadi H. Analisa Dampak Kepemimpinan Karismatik terhadap Kinerja Karyawan di Pemerintah Daerah Kabupaten Sukoharjo. Jurnal Ilmiah SINUS. 2016 Apr 14;14(1).

[12] Nurlaili N, Apridar A, Aiyub A. Pengaruh Budaya Organisasi dan Gaya Kepemimpinan Terhadap Kinerja Guru dengan Lingkungan Kerja dan Kepuasan Kerja Sebagai Varibel Intervening pada Guru SMA di Kecamatan Dewantraa Kabupaten Aceh Utara. J-MIND (Jurnal Manajemen Indonesia). 2020 Dec 29;4(1):119-33.

[13] Idris M, Sari DN. Pengaruh Kepemimpinan dan Disiplin Kerja Terhadap Kinerja Karyawan: Studi Kasus PT Sucofindo Palembang Indonesia. Journal Management, Business, and Accounting. 2019 Apr 20;18(1):76-84. 